\title{
Migration in the Face of Unemployment and Unemployment Risk: a Case Study of Temporal and Regional Effects
}

\author{
Stefanie A. Kley
}

\begin{abstract}
This article employs an elaborated model of migration decision-making and behaviour to analyse the influence of individually experienced unemployment and unemployment risk. Following a contrast group design, respondents from two cities in Germany with different levels of economic prosperity are compared using event history data from a tailor-made panel study. According to a micro-economic approach to migration it is expected that respondents living in an economically deprived city are more likely to decide in favour of migration and actually move compared to those living in a prosperous city because they often perceive opportunities as better elsewhere than at their current place of residence. Moreover, perceiving a risk of becoming unemployed in the near future might trigger migration decisionmaking more in a deprived city because difficulties to find a new job at the place of residence are anticipated. On the other hand, the new household economics approach and the theory of social networks stress the importance of the meso level. Individuals seldom decide in favour or against migration solely; the family rather makes joint decisions. Former research revealed that for unemployed people social networks are a major source for social support and are therefore especially important. There is evidence that in deprived regions social networks deter individuals stronger from moving than in others. These theoretical considerations and findings lead to the expectation that once people are unemployed they seldom leave deprived regions, what is at odds with the expectations from micro-economic theory.

The analyses reveal that the perceived risk of becoming unemployed indeed triggers migration decision-making, but exclusively in the deprived city, whereas people who are already unemployed do not consider or plan leaving the city more often than employed people. Nevertheless, having a partner, children and family at the place of residence might outweigh the impact of a perceived unemployment risk on migration decision-making. When it comes to putting migration plans into action, it is found that the unemployed living in the deprived city are significantly more often constrained from moving compared to the unemployed living in the prosperous city. The analyses suggest that a concentration of social networks at the place of residence primarily accounts for this effect.
\end{abstract}

Keywords: Decision-making · Event history analysis · Migration · Social ties · Unemployment 


\section{Introduction}

In modern societies, unemployment is one of the most feared risks in everyday life. According to data from the German General Social Survey (ALLBUS), in $200810 \%$ of the wage and salary earners in Germany worried about becoming unemployed in the near future. There are still striking economic differences between the eastern and the western parts of Germany that find their expression in the distribution of this fear across the country. In Western Germany, $8 \%$ of the workforce was worried about becoming unemployed in the near future, while in Eastern Germany $19 \%$ did so (Terwey/Baltzer 2009; Terwey 2010: 77). As the interviews were conducted before the beginning of the worldwide financial crisis, between March and April 2008 , these figures may be interpreted as conservative. In contemporary societies, the damage caused by unemployment to the individuals and their family may be considerable, although the loss of income is buffered by welfare systems in more developed countries. Given this background, it is plausible to expect that just perceiving a risk of becoming unemployed may induce job search activities. It is also plausible that people living in economically relatively deprived regions, like in Eastern Germany, have greater incentives to spread the search radius beyond their actual place of residence. Spreading search activities in turn enhances the chance of actually finding a job in a greater distance, what then leads to the necessity of longdistance commuting or moving. The goal of this article is to analyse these temporal and regional effects of unemployment on the probability of migration in greater detail, making use of a more elaborated model of migration decision-making and migration behaviour.

The questions whether and why individuals move in the face of unemployment is usually analysed within a micro-economic model of migration (Pissarides/ Wadsworth 1989; Molho 1995; Böheim/Taylor 2002; Ahn et al. 1999). According to this approach to migration, actors seek to maximise lifetime earnings and therefore invest in migration if the expected returns exceed the costs (Sjaastad 1962; Borjas 1994). Unemployment is assumed to be an important trigger for migration, given that the chance of finding a job is perceived to be greater elsewhere than at the place of residence (Todaro 1969). The incentive to spread search activities for a job across the city boundaries becomes greater the higher the perceived risk of becoming unemployed and the lower the expectancy of finding adequate employment at the place of residence. Empirical evidence shows that unemployed people are indeed more likely to migrate than employed people (Pissarides/Wadsworth 1989; Böheim/Taylor 2002), and that employment reasons have a strong impact on longdistance moves (e.g. Wagner 1989; Kalter 1997; Böheim/Taylor 2002; Kley 2009).

At an aggregate level, micro-economic theory predicts high out-migration figures for deprived regions, that is to say, for regions with high unemployment rates and low income levels, whereas prosperous regions are expected to gain population. At a relatively large regional level, these expectations are often met, i.e. at the level of countries or regions like the Länder in Germany (Geis 2005; Mai 2004). At a smaller regional level, however, the expected correlation between economic prosperity and migration balance often "disappears" (for Germany see (Schlömer/Bucher 2001). 
Immigration and emigration rates frequently appear to be rather highly correlated at the level of small regional entities (Tervo 2000). Making use of multilevel analysis, Windzio (2004) showed that in Germany the rate of transitions between labour market regions even falls as the rate of unemployment rises. Furthermore it was found that a high rate of unemployment deters the unemployed more strongly from moving than the employed (Windzio 2010).

For a more detailed analysis of the influence of unemployment on the migration process a more elaborated three-stage model of migration decision-making and behaviour is applied. This model is not exclusively built on cost-benefit considerations - which are prominent in the microeconomic approach - but on psychological concepts, especially the Theory of Planned Behaviour and its precursor (de Jong/ Fawcett 1981; Kalter 1997; Lu 1998) and, more recently, on the Rubicon Model (Kley 2009, 2011). ${ }^{1}$ Apart from important socio-demographic characteristics the threestage-model of migration includes perceived opportunity differentials between the place of residence and alternative places, psychological dispositions like the feeling of closeness to the place of residence, and local ties inside and outside the household boundaries. Psychological dispositions and local ties - although they could be seen as non-monetary costs - were not explicitly accounted for in micro-economic models, as they were assumed to be of minor influence (Sjaastad 1962). Social ties within the same household gained importance with the new economics of migration theory (Stark 1991): It assumes that rather than the individual income the family income is maximised instead. But social ties outside the household boundaries are usually not accounted for in migration research (Mulder 2007; Haug 2008), apart from contributions that explicitly draw on the social capital approach to migration as introduced by Portes (1995). My questions are (1) whether perceiving a risk of becoming unemployed in the near future generally triggers migration decision-making and succeeding migration behaviour; (2) whether feared or actual unemployment triggers migration decision-making in an economically deprived region to a greater extend compared to a relatively affluent region; (3) whether social networks at the place of residence deter the unemployed from forming migration intentions and from actually moving; and (4) whether the latter is more strongly the case in a deprived compared to a prosperous region.

For the analysis of these questions data from a three wave panel study conducted between 2006 and 2008 among a sample of respondents aged 18 to 50 years at the time of the first interview is used. Following a contrast group design, the data was gathered in two medium sized cities that are similar in important structural characteristics but economically different (cf. Williams/Windebank 2002); Magdeburg in Eastern Germany (the deprived region) and Freiburg in Western Germany (the prosperous region). In the years before the survey began Magdeburg continuously lost population due to a negative migration balance, whereas the opposite was true for Freiburg. The analyses are based on interviews with 1,165 respondents

1 For the Theory of Planned Behaviour see e.g. Ajzen 1985; Ajzen/Madden 1986; for the Rubicon Model see e.g. Heckhausen 1991 and Gol/witzer 1996. 
who participated from the first until the third wave. To uncover the influence of unemployment on each stage of the migration process separate analyses were conducted for the different stages of the migration process - considering and planning leaving the city on the one hand and actually moving on the other - using logistic regressions. Exclusively moves over a distance of more than 50 kilometres are defined as migration; inner-city moves and moves into the close surroundings of the cities are defined as short-distance moves. Migration decision-making is analysed cross-sectionally with data from the first wave, migration behaviour is analysed longitudinally over the 36 months of the survey, making use of discrete time event history models.

\section{Theory and state of research}

\subsection{Three-stage model of migration}

For the analytical framework of migration decision-making and behaviour, an adaptation of the Rubicon model (Heckhausen 1991; Gol/witzer 1996) within a three-stage model of migration was recently suggested (Kley 2009, 2011). In the pre-decisional phase moving comes to mind and lots of aspects are considered, but thoughts are dropped again easily without severe consequences for succeeding behaviour. If weighing the pros and cons leads to a decision in favour of migration, the actor enters the second stage of the migration process. Now concrete plans are made and preparatory actions are undertaken to realise moving intentions. Abandoning plans is now costly, at least in psychological terms, so that planning a certain behaviour - like leaving the city - is expected to be highly predictive for actually realising it. Metaphorically speaking the actor "crossed the Rubicon" (see Fig. 1). In the analyses, the pre-decisional phase is represented by considering migration, whereas the pre-actional phase is represented by planning it. Both considering and planning migration comprise the phase of migration decision-making. Realising the decision in favour of migration - the actional phase - comprises the act of moving.

\subsection{Unemployment and migration}

According to the microeconomic theory actors maximise lifetime earnings and invest in migration if the expected returns exceed the costs (Sjaastad 1962; Borjas 1994). Highly educated and young people are especially mobile because they strive for having their investments in education rewarded and also because they have much prospective earnings to loose in the case of un- or underemployment. Moreover, young people have fewer non-monetary constrains that may deter them from moving compared to older ones, i.e. smaller households and fewer household assets (Sjaastad 1962). Unemployment is assumed to be an important trigger for migration, given that the chance of finding a job is perceived to be greater elsewhere than at the place of residence (Todaro 1969). Former research found that unemployed people are indeed more likely to migrate compared to the employed (e.g. 
Fig. 1: Model of migration in the face of unemployment

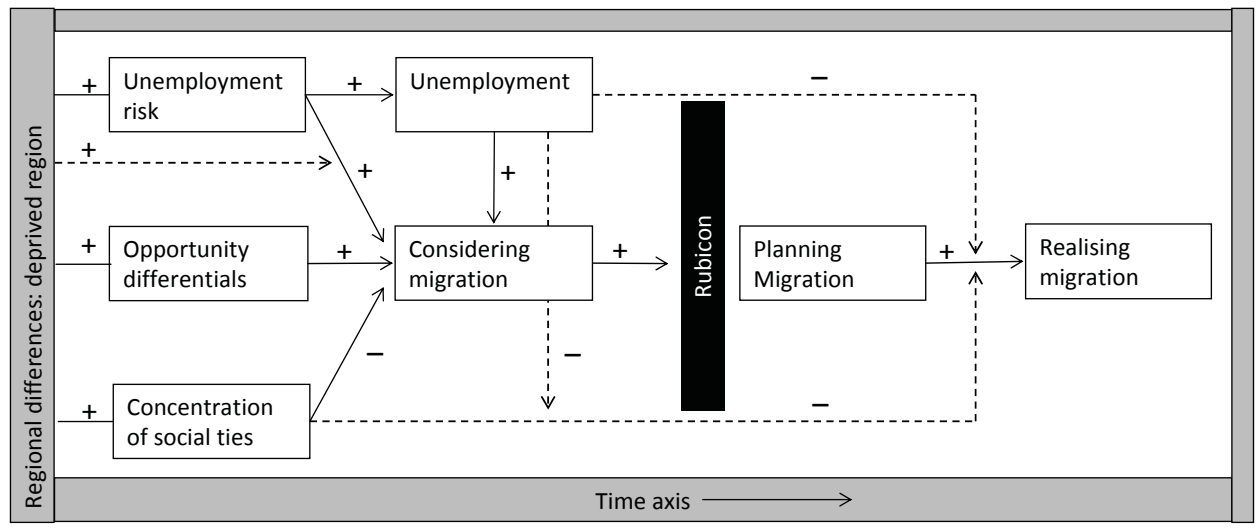

Source: own design

Da Vanzo 1981; Pissarides/Wadsworth 1989; Böheim/Taylor 2002), whereas finding a job is among the most important motives for moving among the unemployed (Détang-Dessendre 1999). Generally, the anticipation of beginning a job is among the most influential triggers for deciding in favour of migration (e.g. Huinink/Kley 2008; Kley 2011). The findings about the influence of regional characteristics like unemployment differentials or vacancy rates on migration are mixed (Pissarides/ Wadsworth 1989; Böheim/Taylor 2002; Fischer/Malmberg 2001). The individual labour market status appears to be far more important as characteristics of the labour markets, or, in the words of Böheim and Taylor (2002): "it is labour demand rather than labour supply that is the important determinant of migration." With the threestage model of migration one can expect that perceiving regional opportunity differentials, perceiving a risk of becoming unemployed, and already being unemployed all trigger considering and planning migration (Fig. 1). The effects of anticipated unemployment are expected to be greater in an economically deprived region as in a prosperous region, because in deprived regions people may have fewer hopes to find an adequate job in their home town and therefore spread search activities early. Usually, succeeding migration behaviour is expected to be not directly influenced by these issues but via migration intentions, with one exception (not depicted in Fig. 1). If a job offer comes at a very short notice, it may appear that people move without having planned it before. We can therefore expect that unemployment also triggers unexpected moves. ${ }^{2}$

2 De Groot et al. 2011 found that becoming unemployed enhances the chance of moving compared to being stable employed, but does so exclusively among people who had no intention to move. 


\subsection{Social networks and migration}

The above straightforward expectations - based on the assumption that the unemployed have a strong desire to find work quickly - may be challenged by other life-spheres that are equally important for the "production" of individual well-being (Lindenberg 1996). Social networks are central in the embeddedness approach in economic sociology. Haug (2008) gives a good overview of the hypothesis derived from this approach with regard to the influence of community and social ties on migration. Having relatives and friends at the place of residence is hypothesized to reduce the tendency to migrate, as do feelings of closeness to the community, and local investments (Affinity hypothesis). Empirical research has shown that larger numbers of close friends living nearby reduce the probability of migration (Belot) Ermisch 2009); the same is true for locally concentrated kinship and friendship networks at the place of residence and for strong feelings of closeness to the place of residence (Kley 2009, 2011). Well known constraints from moving are furthermore living in a self-owned home (e.g. (Wagner 1989; Kalter 1997; de Groot et al. 2011) and living together with a partner, unless the partner himself wants the move (e.g. Kley 2009, 2011). Difficulties in joint decision-making, especially in big households and if both partners have to find work at a possible new destination, are another plausible explanation for these effects (Kalter 1997: 216). The degree of social embeddedness is expected to rise with the length of stay. Findings that people who were born at their actual place of residence have a lower chance for migration compared to others (Kley 2009, 2011), and that the probability of migration falls as the duration of residence in a given region rises (Molho 1995; Fischer/Malmberg 2001) support this view. Therefore it can be expected that a high degree of local embeddedness generally discourages people from migration decision-making (Fig. 1). It is then an empirical question whether the deterring effects of local social networks might outweigh the forcing effects of perceived opportunity differentials and perceived unemployment risks.

Correspondingly, more widespread social networks can be expected to enhance the probability of migration (Haug 2008), as social support from relatives and friends at possible destinations becomes more likely (Kley 2009: 149-156). Certain places may gain attraction because those people give information about living conditions and opportunities, for instance about the labour or housing market (Information hypothesis). Furthermore, social ties at the destination may help with the search for jobs or provide a temporal place to stay (Facilitating hypothesis). Research on international migration found rich empirical evidence for the hypothesized mechanisms, which may induce chain migration processes (e.g. Palloni et al. 2001; Winters et al. 2001). With regard to internal migration it was found that the amount of support given by family members is higher the closer they live to each other (e.g. Lauterbach 2004; Mulder/van der Meer 2009). A concentration of social ties at the place of residence can therefore be expected to have also negative effects on realising intended moves because migration is not supported by locally concentrated networks (Fig. 1). Furthermore, it can be expected that unemployed people may not be able to put migration plans into action because their own monetary resources 
are very limited. According to former findings having some monetary resources facilitates putting migration intentions into action (Moore 1986; Lu 1998; Fang 2006; Kley 2009, 2011).

\subsection{Regional Differences}

For the unemployed social ties, especially a partner, are important sources for social support. Russel (1999) found that for unemployed people social networks at the place of residence often gain importance, especially if they reside in economically deprived regions. Furthermore, regional differences with regard to the characteristics of social support were found. In contrast to higher-income neighbourhoods, in lower-income neighbourhoods self-provisioning work is largely undertaken by friends or relatives for the purpose of sociability and redistribution; "it is monetized mutual aid" (Williams/Windebank 2002: 245). These findings suggest that unemployed people living in economically deprived regions may feel more deterred from moving by local social networks compared to those living in more prosperous regions.

With regard to Germany there is empirical evidence that social ties have a greater impact on everyday life in the eastern part compared to the western part, due to historical reasons (cf. Diewald 1995; Völker/Flap 2001). For people living in Eastern Germany social cohesion of family and friendship ties is more important and their networks provide more emotional and economic support in times of crises (Bräh/er et al. 1996). Other findings from social psychology suggest that in economically deprived regions individually experienced unemployment is less often attributed to personal failure and more often to unfortunate circumstances than in prosperous regions (Pinquart et al. 2008). Additionally it was found that the well-being of the unemployed is strongly positively correlated with the proportion of reference group unemployment at the regional level, and that people whose well-being declined most when becoming unemployed are less likely to remain unemployed (Clark 2003). In light of these findings for unemployed people living in economically deprived regions a lower chance for realising migration intentions is expected compared to those living in more prosperous regions, because locally concentrated networks are expected to have a greater deterring impact on the unemployed living in deprived regions (Fig. 1).

\section{$3 \quad$ Similarities and variations between the two cities}

The two cities in the study, Magdeburg and Freiburg, are quite similar apart from their different economic conditions due to their location in Eastern (Magdeburg) versus Western Germany (Freiburg). They both have about 200,000 inhabitants, both have universities, and both are not located close to another city. These are important parameters with regard to migration, because it is well known from migration research that the number of opportunities for work and education, and the relative closeness to these opportunities in terms of commuting distance, impact 
the propensity to migrate (Boyle et al. 1998). However, Freiburg residents are possibly in a better position with regard to commuting distance than Magdeburg residents. Freiburg is situated in the lower Rhine region that is particularly affluent and also profits from good road and railway connections. Consequently, the influence of (anticipated) unemployment on spatial mobility for Freiburg residents might therefore be somewhat underestimated in the following analysis since they can commute more easily.

There are some striking macro indicators for the different labour market conditions in both cities. ${ }^{3}$ For instance, in 2007 the unemployment rate was $17 \%$ in Magdeburg but $9 \%$ in Freiburg, and the average annual income per employee was $€ 21,000$ in Magdeburg but $€ 26,000$ in Freiburg. In the years before the survey began, Magdeburg regularly lost population due to a negative migration balance whereas Freiburg gained new inhabitants due to migration. Previous research correspondingly revealed that significantly more Magdeburg residents perceived their career and income prospects to be better elsewhere than in their city of residence compared to respondents living in Freiburg (Kley 2009; Kley/Mulder 2010).

\section{Data, methods and variables}

\subsection{Data}

All data was collected in Computer Assisted Telephone Interviews (CATI). Using the Random Digit Dialing method (Gabler et al. 1998; Gabler/Häder 2002), stratified samples of people aged 18 to 50 years living within the city boundaries of Magdeburg and Freiburg were drawn at the beginning of 2006. For each of the cities, the sampling scheme envisaged strata consisting of 250 respondents who had lived for less than twelve months in the city (immigrants), 600 respondents who had lived there for at least twelve months and were not considering leaving, and 600 respondents who had lived there for at least twelve months and were considering leaving the city. ${ }^{4}$ The 500 immigrants were not asked whether they were considering or planning to leave the city and they were not part of the panel study; therefore the first wave of the panel comprises a total sample of 2,410 interviewees. 2,288 of these agreed to take part in follow-up interviews. The response rates in the second and third waves, that took place about one and two years after the first interview, were between 69 and $75 \%$. In the third and final wave, 1,180 respondents were reached.

$\overline{3}$ All figures are official data obtained from the internet platform http://www.insm-wiwo-staedteranking.de/

4 To keep the sampling time short, the immigrant sub-sample was supplemented by official data The response rates in the sampling recruitment procedure in the two cities were 52 and $47 \%$ respectively. If more than one person aged between 18 and 50 years lived in the household, the person whose birthday was most recent was interviewed. 
Since panel attrition is not randomly distributed across groups of respondents, this feature has to be taken into account when designing the analysis (see section 4.2).

Retrospective life history information covering the time of the survey was gathered on a monthly basis from the participants of the third wave, including questions about the respondent's labour market status and income, that of his or her partner, and about household composition and moving behaviour. To avoid left-censoring of the episodes, the starting date of each status held at the beginning of the panel study (i.e. employed, unemployed, partnership, cohabiting) was recorded. In this article, the data of 1,165 respondents who took part in each wave and who provided complete information on the main variables is used.

\subsection{Dependent variables and methods}

Whether people were considering leaving the city was recorded with the following question (translated from German): "Have you recently thought about moving away from Magdeburg/Freiburg to live somewhere else?" According to the weighted data, $33 \%$ of the Magdeburg residents and $28 \%$ of the Freiburg residents were considering migration. Of these respondents about $30 \%$ in each town had more concrete plans to move within the next twelve months.

For the analysis of migration intentions, a generalised ordered logistic regression (Williams 2006) is estimated on the basis of data from the first wave. This method is suitable for ordinal dependent variables and therefore meets the assumptions that migration decision-making is a process in that considering migration follows not considering it, and planning follows considering the move. The main advantage of generalised ordered logistic regression over ordinal logistic regression is that one does not have to make the assumption that the influence of a predictor is the same on each stage (proportional-odds or parallel-lines assumption). This relaxation of the proportional-odds assumption is important because it was shown that the influence of some life-course events are greater on planning than on considering migration (Huinink/Kley 2008; Kley 2009, 2011). The method estimates the likelihood of considering or planning migration versus not considering it, and the likelihood of planning migration versus considering or not considering it. The software used for this analysis offers a routine to test the proportional-odds assumption for each variable (Williams 2006). It has been used to report for which predictors the proportional-odds assumption has to be rejected at a significance level of $5 \%$. If this is the case, the influences on the stages of considering and planning migration can be seen as significantly different. ${ }^{5}$

Migration behaviour is defined as the first move over a distance of more than 50 kilometres within the observation window. Respondents who moved within the city or beyond the city boundaries within a radius of 50 kilometres are still "at risk". Since we know from migration research that people who move often have a higher

5 For all analysis Stata 9.2 and newer versions were used. 
risk of moving again (Massey et al. 1993; Boyle et al. 1998), moving within a short distance is considered an independent variable in the estimation of migration behaviour.

For the analysis of migration behaviour, a longitudinal dataset was constructed. The observation period spans from January 2006 to December 2008 and covers 36 months, resulting in a sample size of 37,523 person months. Of the 1,165 interviewees, 139 migrated within the three year observation period, which corresponds to almost $9 \%$ of the population (weighted). Binomial logistic regression is used to perform a discrete time event history analysis (Allison 1982). To avoid left-censoring at the time of the first interview, the previous duration of each initial status (employment status including being in education or other; time spent in current flat and city; duration of living together with current partner) was considered in the estimation (Guo 1993). For the sake of parsimony status durations that exerted no significant influence were excluded from the models. To capture unobserved heterogeneity among individuals, age was constructed time dependently. ${ }^{6}$

To correct for sample stratification, frequency weights were applied in the descriptive statistics and probability weights were applied in the models. Although correcting for sample selection bias is not necessary to track down causal effects in a well-specified model, it is recommended when sampling weights are a function of the dependent variable (Winship/Radbill 1994). This is the case in Table 2, where considering leaving the city is a category of the outcome variable and respondents considering a move have been over-sampled. In these situations, correcting for sample selection bias provides consistent estimates of the true regression slopes. In Table 3, realising migration is the outcome variable and the item of stratification (considering moving) is included as a predictor. Generally, weighting is not necessary and not recommended here because of a loss in efficiency of the parameters (Winship/Radbill 1994). But in this case, the dependent variable is a function of the sampling variable too, because of selective panel attrition among the groups. Attrition was lowest among respondents who had not considered migration, medium among those who were considering migration and highest among those who were planning it (Kley 2009). To correct for this bias, longitudinal design weights were constructed on the basis of the likelihood estimation of participating in the third wave of the survey. The applied probability weights in the models therefore correct for both sample selection bias and selective panel attrition. The statistical program used for the analysis takes into account that weighting induces heteroskedasticity in the error terms and provides heteroskedastic consistent (robust) standard errors.

\subsection{Independent variables}

Table 1 displays the distribution of predictors with regard to the percentages of respondents who did not consider, considered or planned leaving the city in the first wave and with regard to those who actually migrated. For metric variables the mean

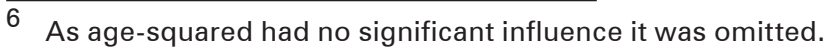


Tab. 1: Distribution of independent variables with regard to people who considered leaving the city or planned to do so in the following 12 months (both estimated in the first wave), and those who migrated within 36 months

\begin{tabular}{|c|c|c|c|c|c|}
\hline Independent variables & $\begin{array}{l}\text { Percent (mean) } \\
\text { not considering } \\
\text { or planning }\end{array}$ & $\begin{array}{l}\text { Percent (mean) } \\
\text { considering }\end{array}$ & $\begin{array}{l}\text { Percent (mean) } \\
\text { planning }\end{array}$ & $\begin{array}{l}\text { Percent (mean) } \\
\text { migrating }\end{array}$ & $\begin{array}{l}\text { Total count } \\
\text { (mean) }\end{array}$ \\
\hline \multicolumn{6}{|l|}{ Main activity } \\
\hline Employed without risk & 76.1 & 18.1 & 5.6 & 5.1 & 634 \\
\hline Employed with risk & 60.0 & 33.5 & 6.5 & 7.6 & 74 \\
\hline Unemployed & 57.0 & 35.5 & 7.5 & 1.0 & 45 \\
\hline In education & 50.2 & 36.4 & 13.4 & 20.3 & 279 \\
\hline Other & 64.1 & 26.3 & 9.5 & 4.9 & 133 \\
\hline Years in job ${ }^{1}$ & (8.7) & (6.8) & $(4.2)$ & (3.1) & (8.1) \\
\hline Years in unemployment ${ }^{1}$ & (3.5) & (2.9) & $(1.8)$ & $(-)$ & (3.2) \\
\hline City: Freiburg & 70.0 & 22.6 & 7.4 & 9.4 & 610 \\
\hline Magdeburg & 64.2 & 27.2 & 8.6 & 7.8 & 555 \\
\hline Years in city & $(21.9)$ & (16.1) & $(11.8)$ & (8.8) & (19.6) \\
\hline Sex: female & 67.7 & 24.3 & 7.9 & 8.7 & 699 \\
\hline male & 66.1 & 25.8 & 8.1 & 8.5 & 466 \\
\hline Age (years) & $(35.4)$ & $(31.0)$ & $(27.7)$ & $(26.0)$ & (33.7) \\
\hline \multicolumn{6}{|l|}{ Perceived opportunity diff. } \\
\hline Career & 51.9 & 33.8 & 14.3 & 13.1 & 518 \\
\hline Partnership & 36.5 & 39.8 & 23.7 & 16.4 & 166 \\
\hline Family life & 29.6 & 45.9 & 24.5 & 15.6 & 128 \\
\hline Pursue own interests & 41.9 & 39.2 & 18.9 & 10.3 & 144 \\
\hline \multicolumn{6}{|l|}{ Qualification } \\
\hline Tertiary & 69.8 & 22.9 & 7.3 & 7.2 & 510 \\
\hline Upper secondary & 66.4 & 24.9 & 8.7 & 8.7 & 579 \\
\hline Primary or lower second. & 58.4 & 35.1 & 6.5 & 13.6 & 76 \\
\hline Homeownership: yes & 86.9 & 11.0 & 2.0 & 0.9 & 252 \\
\hline No & 61.4 & 28.9 & 9.7 & 10.8 & 913 \\
\hline Strong feeling of closeness to city: Yes & 75.5 & 19.1 & 5.5 & 6.0 & 569 \\
\hline No & 58.5 & 31.0 & 10.6 & 11.2 & 596 \\
\hline All/most friends nearby: Yes & 72.1 & 21.6 & 6.3 & 5.5 & 656 \\
\hline No & 59.6 & 29.9 & 10.5 & 13.0 & 509 \\
\hline All/most relatives nearby: Yes & 76.5 & 19.4 & 4.1 & 2.8 & 313 \\
\hline No & 62.9 & 27.4 & 9.7 & 11.1 & 852 \\
\hline \multicolumn{6}{|l|}{ Partner } \\
\hline $\begin{array}{l}\text { No } \\
\text { Partner in household with no or less than }\end{array}$ & 55.9 & 33.3 & 10.8 & 15.0 & 467 \\
\hline $\begin{array}{l}€ 1500 \text { income } \\
\text { Partner in household with income of at least }\end{array}$ & 70.6 & 24.1 & 5.2 & 2.3 & 138 \\
\hline$€ 1500$ & 80.8 & 14.7 & 4.5 & 3.9 & 328 \\
\hline Partner in household, income missing & 80.8 & 14.1 & 5.0 & 1.5 & 89 \\
\hline Partner lives in town & 61.4 & 28.6 & 10.1 & 9.5 & 81 \\
\hline Partner lives elsewhere & 53.7 & 30.6 & 15.7 & 10.7 & 62 \\
\hline Partner in household wants/has to move & 43.2 & 37.1 & 19.7 & 17.2 & 175 \\
\hline Child(ren) in household: Yes & 78.9 & 17.2 & 3.8 & 2.4 & 438 \\
\hline No & 59.9 & 29.7 & 10.5 & 12.3 & 727 \\
\hline Total, percent & 67.0 & 25.0 & 8.0 & 8.6 & 100 \\
\hline Total, count & 649 & 362 & 154 & 139 & 1165 \\
\hline
\end{tabular}

1 If in first spell in this status.

(-) below five cases

Source: Study "Migration decisions in the life course"; own calculations 
is given. In the following, the construction of more complex predictor variables will be explained and their distribution will be discussed shortly with regard to the current literature.

Occupational status was determined on the basis of the respondent's main activity. "Employed" refers to both full-time and part-time employment and it covers both employees and the self-employed. However, students or pensioners who were working part-time, for instance, were not assigned to this category. Occupational status also encompasses "unemployed"; "enrolled in education" comprising all respondents currently enrolled in any branch of the education system (for instance at school, in an apprenticeship or at university); and "other", comprising, for instance, care givers and pensioners. Data on the perceived risk of becoming unemployed was only collected once at the beginning of the survey for employed respondents. It was measured on a five-point Likert scale. Respondents who perceived a relatively high or very high risk of becoming unemployed were assigned to "employed with risk", the others to "employed without risk".

The figures in Table 1 are in line with the findings of former research. For example, people who are involved in any branch of the educational system consider and plan leaving the city most often compared to other status groups, and a high percentage of them actually moved within the observation window. These percentages correspond with a relatively low mean age of people who form migration intentions and especially of those who really move. The unemployed also consider migration often, but they seldom realise it. People who are employed and perceive a high risk of becoming unemployed in the near future consider and plan leaving the city and actually move more often than their counterparts who do not perceive such a risk.

A glance at the time spent in employment or unemployment reveals that people who form migration intentions and, to an even greater extent, those who move have on average spent less time in their current status. This pattern confirms the "law of intertia": The longer the time spent in a given status, the less likely becomes changing the status. The figures for years already spent in the city point in the same direction.

Perceived opportunity differentials indicate whether the respondent thinks that certain spheres of life could be improved via migration: the job situation (career); the partnership and the opportunities to find a partner for those who have no partner at the moment; family life; the opportunities to pursue personal interests. Perceiving better opportunities elsewhere as at the place of residence goes hand in hand with forming migration intentions and with actually realising migration, as expected (cp. with "Total" at the bottom of Table 1).

Educational qualifications and training has been subdivided into three main categories in accordance with the international classification system ISCED in Germany (OECD 1999; Schroedter et al. 2006/08). "Primary and lower secondary" comprises respondents who are still in school and those who left school with a lower second- 
ary qualification ${ }^{7}$ but do not possess a generally acknowledged certificate of apprenticeship. "Upper secondary level" refers both to respondents who completed lower secondary level education and an apprenticeship ${ }^{8}$ and to respondents who completed school with an upper secondary level qualification that allows them to study ${ }^{9}$ but who have neither an apprenticeship nor a university degree. "Tertiary education" comprises all respondents who completed a course of advanced studies at a university or college of higher education. ${ }^{10}$ The percentages of people who consider migration and actually move become higher the lower the level of qualification (Table 1); this is contradictory to the expectations derived from the microeconomic theory. Interestingly, within the subgroup with the lowest level of qualification the share of unplanned moves seem to be relatively high.

The local embeddedness of the respondents can be considered rather differentiated, although there were no direct questions about support from friends or relatives in the dataset.

- Homeownership indicates whether the respondent currently lives in a selfowned house or flat.

- Feelings of closeness to the city of residence were estimated in the first wave with a seven-point Likert scale from (1) "not at all" to (7) "very strong". People who marked 6 or 7 are considered as having a strong feeling of closeness towards their city of residence whereas the reference category consists of people who do not show such a feeling of closeness.

- The share of relatives and friends who live at the place of residence or in the close surroundings is considered in form of a dummy variable that discriminates between those who have all or most family members and friends nearby and those who have not.

- Whether a spouse or unmarried partner is present was estimated with regard to his or her place of residence, labour market status, income and wish or necessity to move. The partner's income should be a useful proxy for the amount of support he or she is possibly able to provide. Living with a partner includes married and cohabiting couples who share a home and comprises three categories: No partner, a partner with no income or an income of less than $€ 1,500$ a month, and a partner with an income of at least $€ 1,500$ a month. It is assumed that a gross income of at least $€ 1,500$ is necessary to support a joint household properly if one partner becomes unemployed.

- Lastly, living with one or more children in the household is considered in the estimations, as the presence of children might be a hindrance for moving.

7 This category was constructed from the following types of schools: Hauptschule, Realschule, Polytechnische Oberschule and Erweiterte Oberschule $10^{\text {th }}$ grade. Part of this group is a small group of less than ten people who left school without any qualifications.

8 Such certificates are, for instance, Facharbeiter, Berufsfachschulabschluss, kaufmaennische Lehre.

9 These certificates are usually Abitur, Fachabitur, Erweiterte Oberschule $12^{\text {th }}$ grade.

10 This category includes, for instance, the university degrees Bachelor, Master, Diplom, Magister, as well as Fachhochschulabschluss and Meister, Techniker. 
Fig. 2: Examples for differences between the deprived (Magdeburg) and the prosperous city (Freiburg) in the first wave

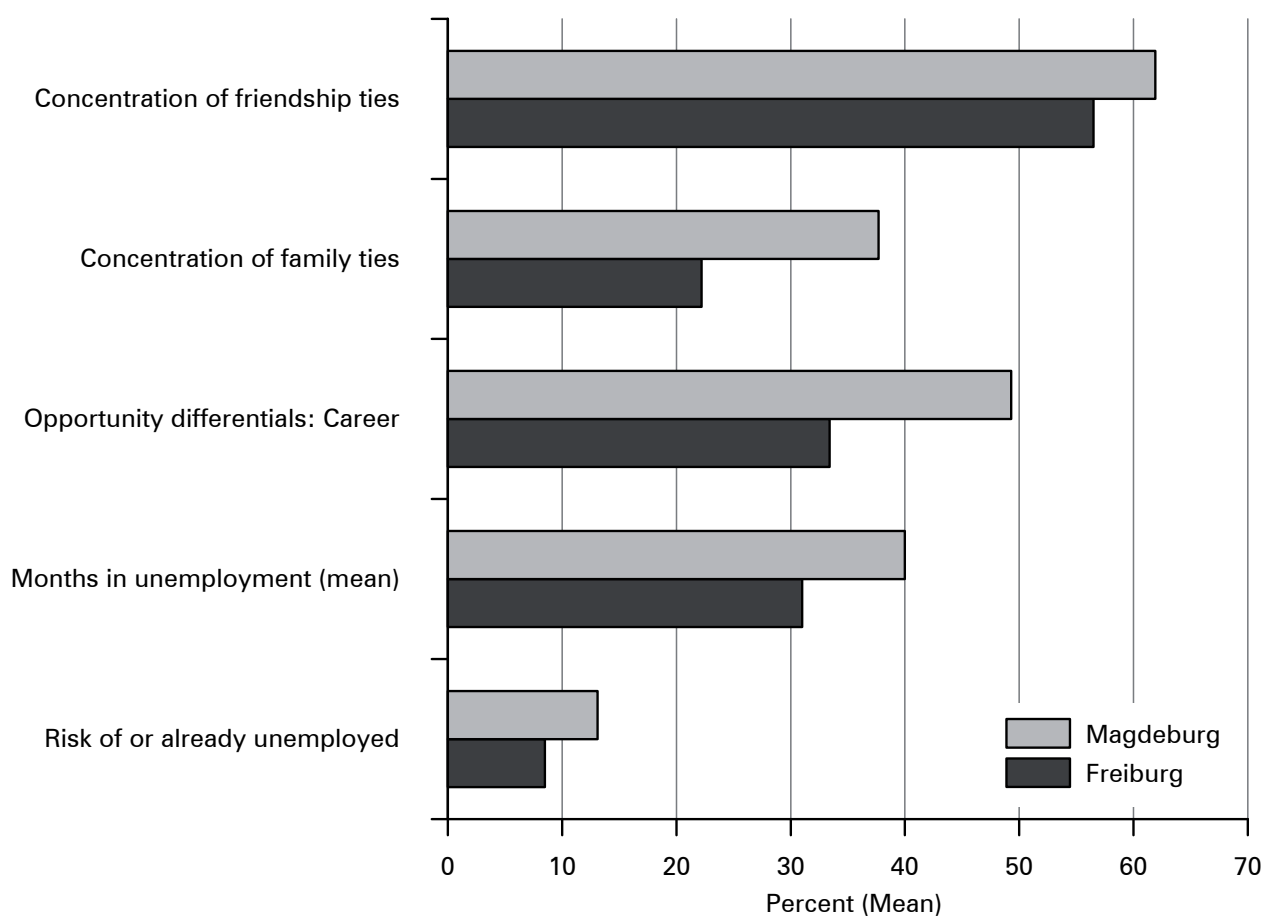

Source: Study "Migration decisions in the life course"; own calculations

Respondents who have all or most relatives and friends at the place of residence consider and plan moving and actually move less often compared to others. The same is true for people who live in a self-owned home, who have a strong feeling of closeness to their city, and those who have a partner and children. The deterring effect of local embeddedness is more pronounced if the couple shares a home, but it changes in its contrary if the partner wants to move.

In the discrete time event history analysis of migration behaviour the main activity was allowed to vary over time. Because the perceived risk of becoming unemployed was only asked once at the beginning of the survey, this information cannot be used in the estimation of migration behaviour. All information about having a partner, living together with him or her, and about his or her income is estimated time dependently, too. The same is true for the information about whether the household owns the house or flat it resides in. Furthermore, the information about considering and planning migration is estimated time dependently. This information was conducted up to five times as it was also asked during short contact interviews between the main waves.

Information about the city of residence, perceived opportunity differentials and the level of qualification were asked in the first wave and are estimated time-con- 
stantly. The presence of children is estimated time constantly but updated at the point in time when a birth occurred.

A look at the differences in the percentages between the two cities with regard to key predictor variables (Fig. 2) reveals that citizens of Magdeburg, the economically deprived city, reported significantly more often to perceive a high risk of becoming unemployed or to already be unemployed compared to citizens of Freiburg, the more prosperous city. Those who reported to be unemployed in the first wave remained in this status for a longer mean duration in Magdeburg. People who live in the deprived region significantly more often perceive their career opportunities as better elsewhere compared to their actual place of residence. Furthermore, they significantly more often report to have all or most of their family members and friends in town or in the close surroundings. Correspondingly, the percentage of residents who reported to have spatially more dispersed networks is higher in the prosperous city.

\section{$5 \quad$ Results}

\subsection{Migration intentions in the face of unemployment and unemployment risk}

In Table 2 the odds of considering and planning migration are estimated with generalised ordinal logistic regression (Williams 2006). In the table, all parameters for the first stage of migration decision making are given (betas: not considering towards considering migration). For most of these parameters the proportional-odds assumption was not rejected. They were therefore constrained to be the same for the second stage of migration decision making and are not displayed separately. The parameters that were estimated to be significantly different for the second stage compared to those of the first stage are displayed as gammas (gammas: considering towards planning migration). They depict deviations from proportionality to the betas for the second stage. In the following tables odds ratios [exp(b)] are given because they can be interpreted as a change in the odds of the outcome due to a one-unit change in a given predictor, holding all other predictors constant (Long 1997: 169).

The first question posed was whether the perceived risk of becoming unemployed may trigger migration decision-making. According to the estimates in Model 1 (Table 2) this question can be answered positively. Compared to respondents enrolled in education - a highly mobile group - a slightly higher risk of forming migration intentions is estimated for employed people who perceive a high risk of becoming unemployed, but the coefficient is not statistically significant. A change in the reference category reveals that significantly higher odds of forming migration intentions are estimated for those employees who perceive a high risk of becoming unemployed compared to those who feel relatively save (not displayed). For those who are already unemployed, this difference is also positive, but not statistically significant. 
Tab. 2: Considering and planning to leave the city

\begin{tabular}{|c|c|c|c|c|}
\hline \multirow{2}{*}{$\begin{array}{l}\text { Generalised ordinal logistic regression (weighted) } \\
\text { Not considering - considering - planning migration }\end{array}$} & \multicolumn{2}{|c|}{ Model 1} & \multicolumn{2}{|c|}{ Model 2} \\
\hline & $\begin{array}{l}\text { Odds } \\
\text { Ratio }\end{array}$ & $\begin{array}{l}\text { Robust } \\
\text { SE }\end{array}$ & $\begin{array}{l}\text { Odds } \\
\text { Ratio }\end{array}$ & $\begin{array}{l}\text { Robust } \\
\text { SE }\end{array}$ \\
\hline \multicolumn{5}{|l|}{ Betas: Not considering towards considering migration } \\
\hline \multicolumn{5}{|l|}{ Main activity (ref. enrolled in education) } \\
\hline Employed without risk & 0.72 & 0.21 & 0.94 & 0.28 \\
\hline Employed with risk & 1.31 & 0.29 & $1.94^{*}$ & 0.37 \\
\hline Unemployed & 0.99 & 0.36 & 1.19 & 0.40 \\
\hline Other & 1.31 & 0.28 & 1.45 & 0.40 \\
\hline City: Freiburg (ref. Magdeburg) & 1.07 & 0.15 & 1.52 & 0.27 \\
\hline Sex: female (ref. male) & 1.12 & 0.14 & 1.12 & 0.14 \\
\hline Age & $0.97^{* *}$ & 0.01 & $0.97^{* *}$ & 0.01 \\
\hline \multicolumn{5}{|l|}{ Perception of opportunity differentials } \\
\hline Career & $3.27 * * *$ & 0.14 & $3.29 * * *$ & 0.14 \\
\hline Partnership & $1.82 * * *$ & 0.22 & $1.70^{* *}$ & 0.26 \\
\hline Family life & $2.76^{* * *}$ & 0.22 & $2.73^{* * *}$ & 0.22 \\
\hline Pursue own interests & $1.92 * * *$ & 0.20 & $1.93^{* * *}$ & 0.20 \\
\hline \multicolumn{5}{|l|}{ Qualification (ref. tertiary education) } \\
\hline Upper secondary & $0.68^{* *}$ & 0.16 & $0.68 * *$ & 0.16 \\
\hline Primary or lower secondary & 0.85 & 0.32 & 0.82 & 0.32 \\
\hline \multicolumn{5}{|l|}{ Local embeddedness } \\
\hline Homeowner (ref. other) & $0.49 * * *$ & 0.21 & $0.50 * * *$ & 0.21 \\
\hline Feeling of closeness to city & $0.85^{* * *}$ & 0.05 & $0.84^{* * *}$ & 0.05 \\
\hline All/most friends in town & 0.92 & 0.15 & 0.91 & 0.15 \\
\hline All/most relatives in town & $0.71^{*}$ & 0.18 & 0.71 & 0.18 \\
\hline \multicolumn{5}{|l|}{ Partner (ref. no partner) } \\
\hline Partner in household with no or less income than $€ 1500$ & $0.48 * * *$ & 0.26 & $0.48^{* * *}$ & 0.26 \\
\hline Partner in household with income of at least $€ 1500$ & $0.58 * * *$ & 0.19 & $0.57^{* * *}$ & 0.19 \\
\hline Partner in household. information about income missing & 0.63 & 0.30 & 0.63 & 0.30 \\
\hline Partner lives in town & 0.75 & 0.25 & 0.75 & 0.26 \\
\hline Partner lives elsewhere & 0.85 & 0.33 & 0.84 & 0.33 \\
\hline Partner wants/has to move & $2.32 * * *$ & 0.20 & $2.36 * * *$ & 0.20 \\
\hline Child(ren) in household & 0.86 & 0.19 & 0.85 & 0.19 \\
\hline \multicolumn{5}{|l|}{ Interactions } \\
\hline Freiburg $\mathrm{x}$ employed without risk & & & 0.59 & 0.33 \\
\hline Freiburg $\mathrm{x}$ employed with risk & & & $0.40^{*}$ & 0.54 \\
\hline Freiburg $x$ unemployed & & & 0.68 & 0.88 \\
\hline Freiburg $x$ other status & & & 0.82 & 0.50 \\
\hline Constant & $2.65^{* *}$ & 0.45 & $2.35^{*}$ & 0.47 \\
\hline \multicolumn{5}{|l|}{ Gammas: Considering towards planning migration } \\
\hline Employed without risk & $1.58^{* *}$ & 0.22 & $1.60^{* *}$ & 0.23 \\
\hline Age & $0.95^{* * *}$ & 0.01 & $0.95^{* * *}$ & 0.02 \\
\hline Primary or lower secondary qualification & $0.38^{* *}$ & 0.49 & $0.38^{* *}$ & 0.49 \\
\hline Number of observations (persons) & 1165 & & 1165 & \\
\hline Wald $\mathrm{Chi}^{2}$ (degrees of freedom) & $314.6(27)$ & & $321.0(31)$ & \\
\hline Model significance & 0.000 & & 0.000 & \\
\hline McFadden Pseudo $\mathrm{R}^{2}$ & 0.197 & & 0.203 & \\
\hline
\end{tabular}

${ }^{*} \mathrm{p}<0.10,{ }^{*} \mathrm{p}<0.05,{ }^{* *} \mathrm{p}<0.01 ; \mathrm{SE}=$ Standard Error

Betas are the parameters for the first stage, considering or planning migration versus not considering and not planning it. Gammas are deviations from proportionality to betas for the second stage, planning migration, versus not considering or considering it Parameters for which the proportional-odds assumption is not rejected at $p<0.05$ are constrained to be the same as betas (that is, gamma $=0$ ) and therefore not displayed separately.

Source: Study "Migration decisions in the life course"; own calculations. 
Model 2 in Table 2 reveals that for both groups of employees as well as for the unemployed lower odds for forming migration intentions are estimated in Freiburg compared to Magdeburg (see interactions). The interaction coefficient is particularly strong and statistically significant for those employees who perceive a high risk of becoming unemployed in the near future. For respondents living in the deprived city, Magdeburg, perceiving a risk of becoming unemployed doubles the odds of considering and of planning migration (Odds ratio $=1.94$ ), whereas in Freiburg these odds are even negative (Odds ratio $=1.94 \times 0.40=0.78$ ). These findings support the idea that in deprived regions the intention to migrate is often formed early, in the face of unemployment risk, because the chances to find work locally are perceived as being low.

The above findings are robust with regard to perceived opportunity differentials between the place of residence and alternative places, which are strong predictors for considering and planning migration (Table 2). Perceiving the career opportunities as better elsewhere more than triples the odds of forming migration intentions, and perceiving better opportunities for the family life is only slightly less important.

The models also show some effects that are well known from previous migration research. With each additional year of age, the odds of considering and planning migration are estimated to be significantly diminished. Compared to respondents who have completed tertiary education, those with lower educational qualifications have lower odds of considering and planning leaving the city. Especially for respondents with upper secondary qualifications significantly lower odds of forming migration intentions are estimated. Further analyses reveal that this effect is stronger in Freiburg, the prosperous city, but the interaction coefficient is not statistically significant (not displayed). This finding suggests that the differences in economic prosperity between the two cities are especially an issue for respondents with medium level qualifications but not for graduates of tertiary education. Since job opportunities for the highly educated are relatively scarce and concentrated in few cities, they might per se have a greater search radius.

Local embeddedness deters people from forming migration intentions, as expected (Table 2). For homeowners the odds of forming migration intentions are estimated to be half those of renters. Having a strong feeling of closeness to the city of residence and having the whole family close by does also significantly diminish the odds of forming migration intentions, whereas a concentration of friendship networks at the place of residence does hardly has such an effect. Living together with a partner halves the odds of forming migration intentions, whereas the deterring influence of a partner with whom the respondent does not share a home is not that strong. An exception from this pattern is formed by respondents whose partners want or have to move; their odds of forming migration intentions are doubled.

Lastly, there are significant differences of some parameters between the two stages of migration decision making (Table 2; gammas). Employees who perceive no risk of becoming unemployed are significantly more likely to decide in favour of moving and to make concrete plans for migration compared to just considering doing so. As a result, for both groups of employees - those who perceive a high risk of becoming unemployed and those who perceive no risk - the odds of deciding in 
favour of migration are estimated to be significantly positive, given that they consider migration as an option. This finding underpins the interpretation that perceiving a high risk of becoming unemployed triggers the very beginning of the migration process. The negative parameter for age suggests that young people more easily decide in favour of migration compared to older ones. Besides, for the least qualified group in the sample significantly lower odds of planning migration compared to considering it are estimated. It seems that part of this group has moving desires but perceives the realisation of these desires as unrealistic.

\subsection{Migration behaviour in the face of unemployment}

In Table 3, the hazard for leaving the city is estimated longitudinally with binomial logistic regression of discrete event history data (Allison 1982). The odds ratios depict a change in the odds of the outcome by a one-unit change in the predictor, holding all other variables constant (Long 1997: 79). As Model 1 shows, planning migration has the single most important impact on actually moving. The very high coefficient $\left(e^{3.24}=25.49\right)$ may be interpreted as a sign of endogeneity: individuals normally do not move without having it planned before. ${ }^{11}$ Keeping this in mind, it is an important finding that in addition to having migration intentions, significantly higher odds of leaving the city are estimated for the unemployed; compared to students enrolled in education, their odds for migration are more than doubled. This finding supports the view that unemployment triggers unexpected moves (cf. de Groot et al. 2011). Interestingly, for employed people almost the same odds of leaving the city are estimated. This also seems plausible, albeit because of other reasons. Having some monetary resources facilitates putting migration intentions into action (Moore 1986; Lu 1998; Fang 2006; Kley 2009, 2011). In accordance with the "law of inertia", the odds of change become lower the longer a status had lasted before the observation started. On average, each additional year in employment or unemployment reduces the chance for migration by $6 \%$.

Perceived opportunity differentials and the educational level of the respondents are barely influential, once earlier stages of migration decision-making are controlled for (Table 3, model 1). A group of people who perceives their opportunities for pursuing personal interests as better elsewhere forms an exception. Those people often appear to be constrained from putting their migration intentions into action.

With regard to local embeddedness there are three different effects present (Table 3, model 1). Living in a self-owned home and having all or most friends at the place of residence deters the respondents significantly from moving. Having a partner who supports the household with a good income does, on the other hand, facilitate realising migration intentions. Respondents with a partner who earns at least $€ 1,500$ gross income a month have more than two times the odds of moving compared to singles. Taking the findings of earlier stages of migration decision-making

$\overline{11}$ Nevertheless, the estimated model reaches convergence within six iterations, and the overall fit of the model is good (McFadden's Pseudo R-squared $=0.207$ ). 
Tab. 3: Realising migration

\begin{tabular}{|c|c|c|c|c|}
\hline \multirow{2}{*}{$\begin{array}{l}\text { Binomial Logistic Regression (weighted) } \\
\text { Mover versus Stayer }\end{array}$} & \multicolumn{2}{|c|}{ Model 1} & \multicolumn{2}{|c|}{ Model 2} \\
\hline & Odds Ratio & $\begin{array}{l}\text { Robust } \\
\text { SE }\end{array}$ & Odds Ratio & $\begin{array}{l}\text { Robust } \\
\text { SE }\end{array}$ \\
\hline \multicolumn{5}{|l|}{ Migration decision-making } \\
\hline Considering migration & $3.92 * * *$ & 0.32 & $3.94 * * *$ & 0.32 \\
\hline Planning migration & $25.49 * * *$ & 0.35 & $25.85^{* * *}$ & 0.35 \\
\hline Internal mover & 1.76 & 0.44 & 1.82 & 0.45 \\
\hline \multicolumn{5}{|l|}{ Main activity (ref. enrolled in education) } \\
\hline Employed & $1.72 * *$ & 0.24 & $1.72 * *$ & 0.24 \\
\hline Unemployed & $2.47^{*}$ & 0.50 & 1.46 & 0.92 \\
\hline Other & 0.60 & 0.51 & 0.61 & 0.51 \\
\hline Years in job or unemployment ${ }^{1}$ & $0.94^{*}$ & 0.03 & $0.94^{*}$ & 0.03 \\
\hline City: Freiburg (ref. Magdeburg) & 1.36 & 0.20 & 1.23 & 0.20 \\
\hline Years in city & $0.96^{* * *}$ & 0.01 & $0.96 * * *$ & 0.02 \\
\hline Sex: female (ref. male) & 0.94 & 0.20 & 0.96 & 0.20 \\
\hline Age & $0.94 * * *$ & 0.02 & $0.94 * * *$ & 0.02 \\
\hline \multicolumn{5}{|l|}{ Perception of opportunity differentials } \\
\hline Career & 1.01 & 0.24 & 0.99 & 0.24 \\
\hline Partnership & 1.08 & 0.26 & 1.09 & 0.26 \\
\hline Family life & 0.90 & 0.27 & 0.93 & 0.27 \\
\hline Pursue own interests & $0.55^{* *}$ & 0.28 & $0.55^{* *}$ & 0.28 \\
\hline \multicolumn{5}{|l|}{ Qualification (ref. tertiary education) } \\
\hline Upper secondary & 1.02 & 0.24 & 1.04 & 0.24 \\
\hline Primary or lower secondary & 1.49 & 0.34 & 1.59 & 0.34 \\
\hline \multicolumn{5}{|l|}{ Local embeddedness } \\
\hline Homeowner (ref. other) & $0.23^{* * *}$ & 0.49 & $0.21 * * *$ & 0.49 \\
\hline Feeling of closeness to city & 1.11 & 0.23 & 1.08 & 0.23 \\
\hline All/most friends in town & $0.59 * *$ & 0.23 & $0.63^{*}$ & 0.24 \\
\hline All/most relatives in town & 0.68 & 0.38 & 0.68 & 0.41 \\
\hline \multicolumn{5}{|l|}{ Partner (ref. no partner) } \\
\hline \multicolumn{5}{|l|}{ Partner in household with no or less income than } \\
\hline$€ 1500$ & 1.16 & 0.38 & 1.22 & 0.38 \\
\hline Partner in household with income of at least $€ 1500$ & $2.83^{* * *}$ & 0.31 & $2.88^{* * *}$ & 0.31 \\
\hline $\begin{array}{l}\text { Partner in household. information about income } \\
\text { missing }\end{array}$ & 0.49 & 0.64 & 0.52 & 0.64 \\
\hline Partner lives in town & 0.94 & 0.35 & 0.97 & 0.35 \\
\hline Partner lives elsewhere & 0.94 & 0.30 & 0.89 & 0.31 \\
\hline Partner wants/has to move & 0.83 & 0.26 & 0.81 & 0.26 \\
\hline Child(ren) in household & 0.59 & 0.36 & 0.61 & 0.35 \\
\hline \multicolumn{5}{|l|}{ Interactions } \\
\hline Unemployed x Freiburg & & & $8.18^{* *}$ & 1.01 \\
\hline Unemployed $x$ all friends in town & & & $0.19^{*}$ & 0.95 \\
\hline Constant & $0.01 * * *$ & 0.63 & $0.01 * * *$ & 0.63 \\
\hline Number of observations (person months) & 37,523 & & 37,523 & \\
\hline Wald $\mathrm{Chi}^{2}$ (degrees of freedom) & $378.6(28)$ & & $401.6(30)$ & \\
\hline Model significance & 0.000 & & 0.000 & \\
\hline McFadden Pseudo $\mathrm{R}^{2}$ & 0.207 & & 0.212 & \\
\hline
\end{tabular}

${ }^{*} \mathrm{p}<0.10,{ }^{* *} \mathrm{p}<0.05,{ }^{* * *} \mathrm{p}<0.01 ; \mathrm{SE}=$ Standard Error

${ }^{1}$ If in first spell in this status.

Source: Study "Migration decisions in the life course"; own calculations 
into account, these findings suggest that families and couples are less likely to form migration intentions compared to single people, but once a migration intention has been formed, couples with a good income are more likely to move. Unfortunately, the unemployed do not seem to profit from such a constellation since the proportion of respondents who reported a partner with a good income was low within this group.

In Model 2 in Table 3 two interaction effects with the status "unemployed" on the odds of migration have been tested (cp. Fig. 1). First, there is a significant interaction effect for the unemployed with the city of residence. In Freiburg, for the unemployed the odds of leaving the city are estimated to be about eight times the odds as in Magdeburg. This finding suggests that exclusively in Freiburg, the prosperous city, unemployed people move unexpectedly, but not in Magdeburg (Odds ratio $=1.46$, not sig.). One piece of the explanation can be found in the influence of social networks. For the unemployed whose friendship networks are spatially concentrated at the city of residence an overwhelming reduction by $80 \%$ in the odds of migration is estimated (Odds ratio $=0.19$ ). Since in the economically deprived city, Magdeburg, the social networks are on average spatially more concentrated compared to Freiburg (see Fig. 2) people living in the deprived city have less social ties at possible destinations that may support them. Interestingly, having the whole family in the city of residence and the close surroundings does not discourage the unemployed much stronger from moving as other groups.

However, besides the distribution of networks there must be other parts of the explanation. It might be possible that searching for another job is more often successful in affluent regions, like the lower Rhine area around Freiburg, compared to relatively deprived regions, like the surroundings of Magdeburg. Because concrete job offers often come at short notice, these moves cannot be planned some months in advance and therefore appear as unplanned. On the other hand, people living in Freiburg were found to have significantly higher odds of becoming longdistance commuters compared to people living in Magdeburg (Kley 2010), most likely because of better road and railway infrastructures. The social psychological argumentation presented above offers another explanation. In deprived regions, being unemployed might be perceived as a widespread fate for a considerable part of the workforce. Experiencing an episode of unemployment in such regions does possibly challenge psychological integrity to a lesser extent because becoming unemployed is more often attributed to external circumstances (Pinquart et al. 2008) and because the personal well-being of unemployed people falls less strongly if unemployment is also experienced by other members of the reference-group (Clark 2003). In view of these findings it seems plausible that unemployed people living in economically deprived regions feel less forced to leave their town of residence. Employees who do not share this view would start looking for a job as soon as they perceived a risk of unemployment and might then move for a new job while they are still employed. 


\section{Conclusion}

The aim of this article was to shed more light on the impact of individually expected or experienced unemployment on migration, applying an elaborated three-stage model of migration decision-making and behaviour. Making use of a panel study with a contrast-group design of two cities - which were similar with regard to the main dimensions affecting migration propensity but different with regard to economic prosperity - two fundamental problems were assessed: the time dependency of the migration process and regional differences between the local settings that actors are embedded in.

Firstly, it was hypothesized that a perceived risk of becoming unemployed may trigger the formation of migration intentions, especially in tight local labour markets, because most of the wage and salary earners are probably well aware of the risk that unemployment bears for their standard of living. The analysis showed that perceiving better career opportunities is generally among the most important predictors for considering and planning migration, but perceiving a high risk of becoming unemployed exclusively triggers migration decision-making in the deprived region. For employees living in the deprived region and perceiving a high risk of becoming unemployed in the near future, the odds of considering migration were found to be significantly higher compared to both employees who feel their jobs are relatively safe and employees who perceive an unemployment risk but live in an affluent region. Consequently, and referring to my second question, perceiving a risk of becoming unemployed triggers migration decision-making to a significantly higher extent in the deprived city compared to the prosperous city.

For those who are already unemployed, no significant difference in the odds of forming migration intentions was found between the two cities. As hypothesized with the three-stage model of migration, planning to leave the city was found to be the most important predictor for migration behaviour, whereas perceived opportunities were found to exclusively trigger migration decision-making but not migration behaviour. Although it was not possible to analyse the influence of perceiving a high risk of becoming unemployed longitudinally, these findings support the view that perceived risks as well as perceived opportunity differentials trigger migration via the early stages of migration decision-making. Therefore, migration research that neglects those stages of migration decision-making and focuses on migration behaviour probably underestimates the extent to which (anticipated) unemployment triggers migration, especially out of deprived regions.

With regard to regional differences, two theoretical approaches were presented that led to different expectations. According to the microeconomic approach, unemployed people were expected to migrate more often compared to employed people, mainly because overall the unemployed should have lower moving costs and relatively high moving incentives. Therefore, in economically deprived regions relatively high unemployment figures were expected to result in high out-migration propensities. On the other hand, according to the new household economics and social network theory, having a partner, children and other kinship and friendship networks at the place of residence should deter people from moving. As findings 
from previous research showed that social networks are especially important for the unemployed, and that they are especially influential in economically deprived regions, the opposite outcome was also plausible: In deprived regions the unemployed are particularly strongly deterred from moving due to strong local networks and social embeddedness.

Therefore, the third question analysed was whether social networks at the place of residence deter the unemployed from forming migration intentions and from actually moving. The analyses showed that living together with a partner who does not want to move, having most family members at the place of residence, having strong feelings of closeness to the city and living in a self-owned home indeed deter individuals strongly from migration decision-making. The deterring effects of local embeddedness might outweigh the pushing effects of a perceived unemployment risk and perceived opportunity differentials. Having a partner in a separate home, having children and having most friends at the place of residence has some but no significant negative influence on migration decision-making. As in the economically deprived city kinship and friendship networks are on average more concentrated compared to the affluent city, one may conclude that they are more often deterred from moving for reasons of local embeddedness.

Furthermore, regional effects on the last stage of the migration process were found. The unemployed living in the deprived city were found to be more often constrained from realising their migration intentions, whereas the unemployed living in the prosperous city were more often successful. One piece of the explanation can be found again in the spatial distribution of friendship networks which confirms the fourth hypothesis: Having all or most friends at the place of residence does especially deter the unemployed from realising migration intentions, most likely because local friendship networks are particularly important for them. Additionally, the odds of realising migration were found to decrease significantly with each year the respondents have been living in town and with each year they have been working in their current job or - even more strongly - have been unemployed. These are further temporal effects, well known in migration research as "law of inertia". This "law" has a stronger impact on inhabitants of economically deprived regions because on average they have been living at their actual place of residence for a longer time period and if in this status they are unemployed for longer time periods.

Additional findings support this view. In line with former research it was found that having some monetary resources facilitates the realisation of migration intentions. Therefore, employed people and those who live with a partner who earns a good income are more likely to realise migration intentions, but unfortunately the unemployed rarely live with a good-earning partner. Findings from social psychology suggest that for people living in economically deprived regions the experience of unemployment might not be as activating as for those living in prosperous regions because unemployment is perceived as a widespread fate within the reference group (Clark 2003; Pinquart et al. 2008). This hypothesis could not be assessed further on the basis of the dataset used.

The findings confirm the expectations derived from the new household economics and social network theory, and they are at odds with those derived from the 
microeconomic theory. They are robust with regard to other influences that are well known from previous research (cf. Boyle et al. 1998), e.g. age and level of qualification, and the overall fit of the models is good. But it should be kept in mind that the analysis was based on a three year panel and made use of a relatively small sample of 1,165 respondents living in two different towns. Although the sampling scheme and the questionnaires were explicitly theory based and the samples were drawn carefully, this might inhibit the generalisability of the results.

Nevertheless, a few comments on the policy implications that may be derived from the results should be given. Firstly, the process character of migration decision-making could be given more attention by offering early support to people who perceive a risk of becoming unemployed. The employee's duty to announce the termination of a job contract some weeks in advance, as is the case in Germany, points in the right direction. But the findings also show clearly that family members and friends have an impact on the individual's inclination to migrate. Measures for bringing the unemployed in work should therefore not only focus on individual clients but consider the situation of the couple and the family instead.

Especially in economically deprived regions, the embeddedness in social networks at the place of residence might be a major deterrent for even considering migration. Therefore, in the face of high regional unemployment rates long-distance commuting might be a good alternative strategy. As strong social networks at the place of residence are a major source of social support and, therefore, of social cohesion, the promotion of commuting might be a means to strengthen economically deprived regions in the long run - although commuting bears some risk of being a predecessor of migration.

\section{Funding}

German Research Foundation (DFG).

\section{References}

Ahn, Namkee; La Rica, Sara de; Ugidos, Arantza 1999: Willingness to Move for Work and Unemployment Duration in Spain. In: Economica 66: 335-357 [doi: 10.1111/1468-0335.00174].

Ajzen, Icek 1985: From Intentions to Actions: A Theory of Planned Behavior. In: Kuhl, Julius; Beckmann, Jürgen (Hrsg.): Action Control - From Cognition to Behavior. Berlin: Springer: 11-39.

Ajzen, Icek; Madden, Thomas J. 1986: Prediction of Goal-directed Behaviour. Attitudes, Intentions and Perceived Behavioral Control. In: Journal of Experimental Social Psychology 22,5: 453-474 [doi: 10.1016/0022-1031(86)90045-4].

Allison, Paul D. 1982: Discrete-Time Methods for the Analysis of Event Histories. In: Sociological Methodology 13: 61-98.

Belot, Mechèle; Ermisch, John 2009: Friendship ties and geographical mobility. Evidence from Great Britain. In: Journal of the Royal Statistical Society 172,2: 427-442 [doi: 10.1111/j.1467-985X.2008.00566.x]. 
Böheim, René; Taylor, Mark P. 2002: Tied Down or Room to Move? Investigating the Relationships between Housing Tenure, Employment Status and Residential Mobility in Britain. In: Scottish Journal of Political Economy 49,4: 369-392 [doi: 10.1111/1467-9485.00237].

Borjas, George J. 1994: The Economics of Immigration. In: Journal of Economic Literature 32,4: 1667-1717.

Boyle, Paul; Halfacree, Keith; Robinson, Vaughan 1998: Exploring Contemporary Migration. Harlow/Essex: Pearson.

Brähler, Elmar et al. 1996: Soziale Befindlichkeiten in Ost und West. In: Psychosozial 64: 111-117.

Clark, Andrew E. 2003: Unemployment as a Social Norm: Psychological Evidence from Panel Data. In: Journal of Labor Economics 21,2: 323-351 [doi: 10.1086/345560].

Da Vanzo, Julie 1981: Repeat migration, information costs, and location specific capital. In: Population and Environment 4,1: 45-73 [doi: 10.1007/BF01362575].

Détang-Dessendre, Cécile 1999: Reciprocal link between exit from unemployment and geographical mobility. In: Environment and Planning A 31,8: 1417-1431 [doi: 10.1068/ a311417].

Diewald, Martin 1995: "Kollektiv“, "Vitamin B“ oder "Nische“? Persönliche Netzwerke in der DDR. In: Huinink, Johannes et al. (Hrsg.): Kollektiv und Eigensinn. Lebensläufe in der DDR und danach. Berlin: Akademie Verlag: 223-260.

Fang, Yiping 2006: Residential Satisfaction, Moving Intentions and Moving Behaviours. A Study of Redeveloped Neighbourhoods in Inner-city Beijing. In: Housing Studies 21,5: 671-694 [doi: 10.1080/02673030600807217].

Fischer, Peter A.; Malmberg, Gunnar 2001: Settled People Don't Move. On Live Course and (Im-)Mobility in Sweden. In: International Journal of Population Geography 7,5: 357-371 [doi: 10.1002/ijpg.230].

Gabler, Siegfried; Häder, Sabine 2002: Idiosyncrasies in Telephone Sampling - the Case of Germany. In: International Journal of Public Opinion Research 14,3: 339-345 [doi: 10.1093/ijpor/14.3.339].

Gabler, Siegfried; Haeder, Sabine; Hoffmeyer-Zlotnik, Jürgen H.P. (Hrsg.) 1998: Telefonstichproben in Deutschland. Opladen: Westdeutscher Verlag.

Ganzeboom, Harry; Lindenberg, Siegwart (Hrsg.) 1996: Verklarende Sociologie. Opstellen voor Reinhard Wippler. Amsterdam: Thesis Publishers.

Geis, Martin 2005: Migration in Deutschland. Interregionale Migrationsmotivatoren. Wiesbaden: Deutscher Universitätsverlag [doi: oclc/76948598].

Gol/witzer, Peter M. 1996: The Volitional Benefits of Planning. In: Gol/witzer, Peter M.; Bargh, John A. (Hrsg.): The Psychology of Action. Linking Cognition and Motivation to Behavior. New York: Guilford Press: 287-312.

Gollwitzer, Peter M.; Bargh, John A. (Hrsg.) 1996: The Psychology of Action. Linking Cognition and Motivation to Behavior. New York: Guilford Press.

Groot, Carola de et al. 2011: Life events and the gap between intention to move and actual mobility. In: Environment and Planning A 43,1: 48-66 [doi: 10.1068/a4318].

Guo, Guang 1993: Event-History analysis for left-truncated data. In: Sociological Methodology 23,1: 217-243.

Haug, Sonja 2008: Migration Networks and Migration Decision-Making. In: Journal of Ethnic and Migration Studies 34,4: 585-605 [doi: 10.1080/13691830801961605]. 
Heckhausen, Heinz 1991: Motivation and Action. New York: Springer.

Huinink, Johannes; Kley, Stefanie A. 2008: Regionaler Kontext und Migrationsentscheidungen im Lebensverlauf. In: Kalter, Frank (Hrsg.): Migration und Integration Sonderheft 48. Wiesbaden: VS Verlag für Sozialwissenschaften: 162-184.

Huinink, Johannes et al. (Hrsg.) 1995: Kollektiv und Eigensinn. Lebensläufe in der DDR und danach. Berlin: Akademie Verlag.

Jong, Gordon de; Fawcett, James 1981: Motivations for Migration. An Assessment and a Value-Expectancy Research Model. In: Jong, Gordon de; Gardner, Robert W. (Hrsg.): Migration Decision Making. Multidisciplinary Approaches to Microlevel Studies in Developed and Developing Countries. New York: Pergamon Press: 13-58.

Jong, Gordon de; Gardner, Robert W. (Hrsg.) 1981: Migration Decision Making. Multidisciplinary Approaches to Microlevel Studies in Developed and Developing Countries. New York: Pergamon Press.

Kalter, Frank 1997: Wohnortwechsel in Deutschland. Ein Beitrag zur Migrationstheorie und zur empirischen Anwendung von Rational-Choice-Modellen. Opladen: Leske + Budrich.

Kalter, Frank (Hrsg.) 2008: Migration und Integration, Sonderheft 48. Wiesbaden: VS Verlag für Sozialwissenschaften.

Kley, Stefanie A. 2009: Migration im Lebensverlauf. Der Einfluss von Lebensbedingungen und Lebenslaufereignissen auf den Wohnortwechsel. Wiesbaden: VS Verlag für Sozialwissenschaften.

Kley, Stefanie A. 2010: Multilokalität als Strategie zur Nutzung von Chancen. In: Soeffner, Hans-Georg (Hrsg.): Unsichere Zeiten. Herausforderungen gesellschaftlicher Transformationen. Verhandlungen des 34. Kongresses der Deutschen Gesellschaft für Soziologie in Jena 2008. Wiesbaden: VS Verlag für Sozialwissenschaften: CD-Rom.

Kley, Stefanie A. 2011: Explaining the Stages of Migration Within a Life-Course Framework. In: European Sociological Review 27,4: 469-486 [doi: 10.1093/esr/jcq020].

Kley, Stefanie A.; Mulder, Clara H. 2010: Considering, planning and realizing migration in early adulthood. The influence of life-course events and perceived opportunities on leaving the city in Germany. In: Journal of Housing and the Built Environment 25,1: 73-94 [doi: 10.1007/s10901-009-9167-8].

Kuhl, Julius; Beckmann, Jürgen (Hrsg.) 1985: Action Control - From Cognition to Behavior. Berlin: Springer.

Lauterbach, Wolfgang 2004: Die multilokale Mehrgenerationenfamilie. Zum Wandel der Familienstruktur in der zweiten Lebenshälfte. Familie und Gesellschaft 13. Würzburg: Ergon.

Lindenberg, Siegwart 1996: Continuities in the theory of social production functions. In: Ganzeboom, Harry; Lindenberg, Siegwart (Hrsg.): Verklarende Sociologie. Opstellen voor Reinhard Wippler. Amsterdam: Thesis Publishers: 167-184.

Long, Scott J. 1997: Regression Models for Categorical and Limited Dependent Variables. Advanced Quantitative Techniques in the Social Sciences. Thousand Oaks/London/New Delhi: SAGE Publications.

Lu, Max 1998: Analyzing Migration Decisionmaking. Relationships between Residential Satisfaction, Mobility Intentions, and Moving Behavior. In: Environment and Planning A: 30,8: 1473-1495 [doi: 10.1068/a301473].

Mai, Ralf 2004: Abwanderung aus Ostdeutschland. Strukturen und Milieus der Altersselektivität und ihre regionalpolitische Bedeutung. Frankfurt am Main: Peter Lang. 
Massey, Douglas S. et al. 1993: Theories of International Migration. A Review and Appraisal. In: Population and Development Review 19,3: 431-466.

Molho, Ian 1995: Migrant Inertia, Accessibility and Local Unemployment. In: Economica 62,245: 123-132.

Moore, Eric G. 1986: Mobility Intentions and Subsequent Relocation. In: Urban Geography 7,6: 497-514.

Mulder, Clara H. 2007: The Family Context and Residential Choice. A Challenge for New Research. In: Population, Space and Place 13,4: 265-278 [doi: 10.1002/psp.456].

Mulder, Clara H.; van der Meer, Marieke J. 2009: Geographical Distances and Support from Family Members. In: Population, Space and Place 15,4: 381-399 [doi: 10.1002/ psp.557].

OECD 1999: Classifying Educational Programmes. Manual for ISCED-97 Implementation in OECD Countries. Paris: OECD.

Ostner, Ilona; Krause, Peter (Hrsg.) 2010: Leben in Ost- und Westdeutschland. Eine sozialwissenschaftliche Bilanz der deutschen Einheit 1990-2010. Frankfurt am Main: Campus.

Palloni, Alberto et al. 2001: Social Capital and International Migration. A Test Using Information on Family Networks. In: American Journal of Sociology 106,5: 1262-1298 [doi: 10.1086/320817].

Pinquart, Martin; Silbereisen, Rainer K.; Körner, Astrid 2008: Das Zusammenspiel von Merkmalen der Region mit individuell erlebten wandelbezogenen Anforderungen und deren Bewältigung. In: Silbereisen, Rainer K.; Pinquart, Martin (Hrsg.): Individuum und sozialer Wandel. Eine Studie zu Anforderungen, psychosozialen Ressourcen und individueller Bewältigung. Weinheim/München: Juventa Verlag: 256-290.

Pissarides, Christopher A.; Wadsworth, Jonathan 1989: Unemployment and the InterRegional Mobility of Labour. In: The Economic Journal 99,397: 739-755.

Portes, Alejandro (Hrsg.) 1995: The Economic Sociology of Immigration. Essays on Networks, Ethnicity, and Entrepreneurship. New York: The Russel Sage Foundation.

Russel, Helen 1999: Friends in Low Places. Gender, Unemployment and Sociability. In: Work, Employment and Society 13,2: 205-224 [doi: 10.1177/09500179922117917].

Schlömer, Claus; Bucher, Hansjörg 2001: Arbeitslosigkeit und Binnenwanderungen. Auf der Suche nach einem theoriegestützten Zusammenhang. In: Informationen zur Raumentwicklung 1: 33-47.

Schroedter, Julia; Lechert, Yvonne; Luettinger, Paul 2006/08: Die Umsetzung der Bildungsskala ISCED-1997 fuer die Volkszaehlung 1970, die Mikrozensus-Zusatzerhebung 1971 und die Mikrozensen 1976-2004. ZUMA-Methodenbericht. Mannheim: Selbstverlag.

Silbereisen, Rainer K.; Pinquart, Martin (Hrsg.) 2008: Individuum und sozialer Wandel. Eine Studie zu Anforderungen, psychosozialen Ressourcen und individueller Bewältigung. Weinheim/München: Juventa Verlag.

Sjaastad, Larry A. 1962: The Costs and Returns of Human Migration. In: Journal of Political Economy 70,5, Part 2: 80-93.

Soeffner, Hans-Georg (Hrsg.) 2010: Unsichere Zeiten. Herausforderungen gesellschaftlicher Transformationen. Verhandlungen des 34. Kongresses der Deutschen Gesellschaft für Soziologie in Jena 2008. Wiesbaden: VS Verlag für Sozialwissenschaften.

Stark, Oded 1991: The Migration of Labour. Oxford: Blackwell. 
Tervo, Hannu 2000: Migration and Labour Market Adjustment: Empirical Evidence from Finland 1985-90. In: International Review of Applied Economics 14,3: 343-360 [doi: 10.1080/02692170050084079].

Terwey, Michae/ 2010: German General Social Survey. A Compendium of Standardized Surveydescriptions. Release 2010.09. Cologne: GESIS Data Archive for the Social Sciences.

Terwey, Michael; Baltzer, Stefan 2009: Datenhandbuch ALLBUS 2008. Köln/Mannheim: GESIS.

Todaro, Michael P. 1969: A Model of Labour Migration and Urban Unemployment in Less Developed Countries. In: The American Economic Review 59,1: 138-148.

Völker, Beate; Flap, Henk 2001: Weak Ties as a Liability. The Case of East Germany. In: Rationality and Society 13,4: 397-428 [doi: 10.1177/104346301013004001].

Wagner, Michae/ 1989: Räumliche Mobilität im Lebensverlauf. Eine empirische Untersuchung sozialer Bedingungen der Migration. Stuttgart: Ferdinand Enke Verlag.

Williams, Colin C.; Windebank, Jan 2002: The Uneven Geographies of Informal Economic Activities. A Case Study of Two British Cities. In: Work, Employment and Society 16,2: 231-250 [doi: 10.1177/095001702400426820].

Williams, Richard 2006: Generalized Ordererd Logit / Partial Proportional Odds Models for Ordinal Dependent Variables. In: The Stata Journal 6,1: 58-82.

Windzio, Michael 2004: Kann der regionale Kontext zur "Arbeitslosenfalle“ werden? Der Einfluss der Arbeitslosigkeit auf die Mobilität zwischen regionalen Arbeitsmärkten in Westdeutschland. In: Kölner Zeitschrift für Soziologie und Sozialpsychologie 56,2: 257-278 [doi: 10.1007/s11577-004-0034-z].

Windzio, Michae/ 2010: Die Abwanderung Arbeitsloser von Ost- nach Westdeutschland. Zur "institutionellen Bindewirkung" des Wohlfahrtsstaates. In: Ostner, Ilona; Krause, Peter (Hrsg.): Leben in Ost- und Westdeutschland. Eine sozialwissenschaftliche Bilanz der deutschen Einheit 1990-2010. Frankfurt am Main: Campus: 277-298.

Winship, Christopher; Radbill, Larry 1994: Sampling Weights and Regression Analysis. In: Sociological Methods \& Research 23,2: 230-257 [doi: 10.1177/0049124194023002004].

Winters, Paul; Janvry, Alain de; Sadoulet, Elisabeth 2001: Family and Community Networks in Mexico-U.S. Migration. In: Journal of Human Resources 36,1: 159-184.

A German translation of this reviewed and author's authorised original article by the author is available under the title "Migration bei Arbeitslosigkeit und Arbeitslosigkeitsrisiko: Eine Fallstudie temporärer und regionaler Effekte", DOI 10.4232/10.CPOS-2013-04de or URN urn:nbn:de:bib-cpos2013-04de8, at http://www.comparativepopulationstudies.de.

Dr. Stefanie A. Kley $(\bowtie)$. Universität Hamburg. Fakultät Wirtschafts- und Sozialwissenschaften, Fachbereich Sozialökonomie, 20354 Hamburg, Germany. E-Mail: stefanie.kley@uni-hamburg.de

URL: http://www.wiso.uni-hamburg.de/professuren/institut-fuer-soziologie/personal/ postdoc-angestellte-und-wissenschaftliche-mitarbeiterinnen/stefanie-kley/ 


\section{Comparative Population Studies - Zeitschrift für Bevölkerungswissenschaft}

wWw.comparativepopulationstudies.de

ISSN: 1869-8980 (Print) - 1869-8999 (Internet)

Published by / Herausgegeben von

Prof. Dr. Norbert F. Schneider

Federal Institute for Population Research

D-65180 Wiesbaden / Germany

Managing Editor /

Verantwortlicher Redakteur

Frank Swiaczny

Assistant Managing Editor /

Stellvertretende Redakteurin

Katrin Schiefer

Language \& Copy Editor (English) /

Lektorat \& Übersetzungen (englisch)

Amelie Franke

Copy Editor (German) /

Lektorat (deutsch)

Dr. Evelyn Grünheid

\section{Layout / Satz}

Beatriz Feiler-Fuchs

E-mail: cpos@bib.bund.de

\author{
Scientific Advisory Board / \\ Wissenschaftlicher Beirat \\ Jürgen Dorbritz (Wiesbaden) \\ Paul Gans (Mannheim) \\ Johannes Huinink (Bremen) \\ Marc Luy (Wien) \\ Clara H. Mulder (Groningen) \\ Notburga Ott (Bochum) \\ Peter Preisendörfer (Mainz)
}

\section{Board of Reviewers / Gutachterbeirat} Martin Abraham (Erlangen)

Laura Bernardi (Lausanne) Hansjörg Bucher (Bonn) Claudia Diehl (Göttingen) Andreas Diekmann (Zürich) Gabriele Doblhammer-Reiter (Rostock) Henriette Engelhardt-Wölfler (Bamberg) E.-Jürgen Flöthmann (Bielefeld) Alexia Fürnkranz-Prskawetz (Wien) Beat Fux (Zürich) Joshua Goldstein (Rostock) Karsten Hank (Köln) Sonja Haug (Regensburg) Franz-Josef Kemper (Berlin) † Michaela Kreyenfeld (Rostock) Aart C. Liefbroer (Den Haag) Kurt Lüscher (Konstanz) Dimiter Philipov (Wien) Tomáš Sobotka (Wien) Heike Trappe (Rostock) 